\title{
'Philantropie dynamique'; over de sociologische betekenis van de herintrede van een sector
}

Citation for published version (APA):

Schuyt, T. N. M. (2015). 'Philantropie dynamique'; over de sociologische betekenis van de herintrede van een sector. Maasricht University. https://doi.org/10.26481/spe.20150618ts

Document status and date:

Published: 18/06/2015

DOI:

$10.26481 /$ spe.20150618ts

Document Version:

Publisher's PDF, also known as Version of record

\section{Please check the document version of this publication:}

- A submitted manuscript is the version of the article upon submission and before peer-review. There can be important differences between the submitted version and the official published version of record.

People interested in the research are advised to contact the author for the final version of the publication, or visit the DOI to the publisher's website.

- The final author version and the galley proof are versions of the publication after peer review.

- The final published version features the final layout of the paper including the volume, issue and page numbers.

Link to publication

\footnotetext{
General rights rights.

- You may freely distribute the URL identifying the publication in the public portal. please follow below link for the End User Agreement:

www.umlib.nl/taverne-license

Take down policy

If you believe that this document breaches copyright please contact us at:

repository@maastrichtuniversity.nl

providing details and we will investigate your claim.
}

Copyright and moral rights for the publications made accessible in the public portal are retained by the authors and/or other copyright owners and it is a condition of accessing publications that users recognise and abide by the legal requirements associated with these

- Users may download and print one copy of any publication from the public portal for the purpose of private study or research.

- You may not further distribute the material or use it for any profit-making activity or commercial gain

If the publication is distributed under the terms of Article $25 \mathrm{fa}$ of the Dutch Copyright Act, indicated by the "Taverne" license above, 


\section{Prof. dr. Th.N.M.Schuyt}

School of Business and Economics

"Philantropie dynamique"; over de sociologische betekenis van de herintrede van een sector.
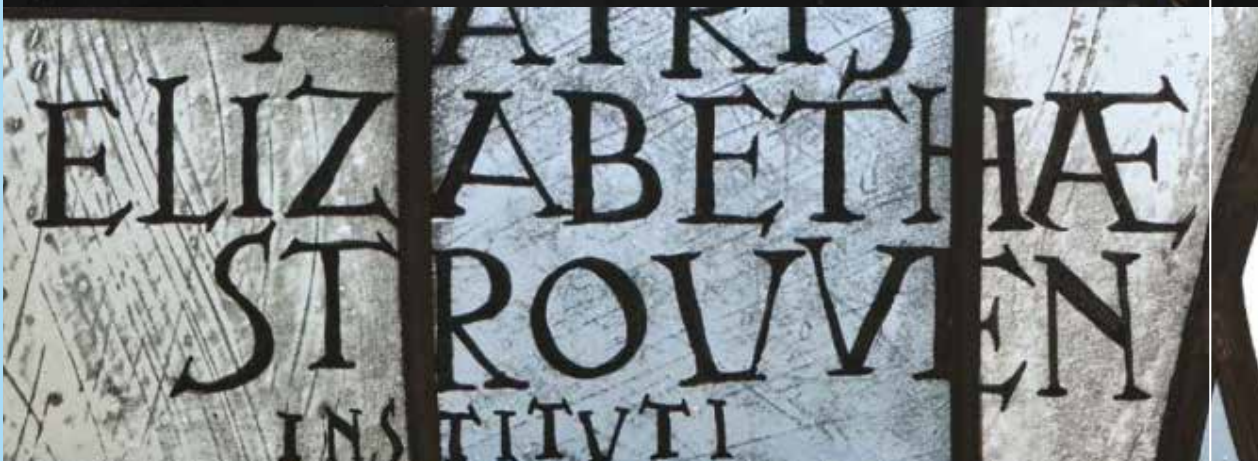
Locatie: St.Janskerk Maastricht

Orgel: Theo van Ballegooy

Zang: Ingrid Stijsiger mezzosopraan 
"Philantropie dynamique"; over de sociologische betekenis

van de herintrede van een sector. 


\section{Colofon}

Design \& print: Canon Business Services, Maastricht

ISBN: 9789056814502

NUR: 780

All rights reserved. No part of this publication may be reproduced, modified, stored in a retrieval system or made public without the prior written permission of the author or publisher. 


\section{"Philantropie dynamique"; over de sociologische betekenis van de herintrede van een sector.}

Inaugurele rede

In verkorte vorm uitgesproken 18 juni 2015, ter gelegenheid van de benoeming als bijzonder hoogleraar "Filantropie en sociale innovatie" vanwege de Stichting Elisabeth Strouven aan de School of Business and Economics van de Universiteit Maastricht.

Maastricht, 18 juni 2015

Door prof. dr. Th.N.M.Schuyt 
Voor Monique en Michiel 
Mijnheer de rector, geachte aanwezigen,

De titel van deze rede is mede ingegeven door de Wetenschappelijke Raad voor het Regeringsbeleid die in haar werkprogramma 2015 het project 'filantropie' heeft opgenomen. Citaat: "Filantropie is universeel en tegelijkertijd persoonlijk en vormt niet alleen een reactie op het falen van de overheid of de markt, maar is ook geïnspireerd door bepaalde waarden of 'verlicht' eigen belang. Filantropie kan dynamiek in sociale systemen aanbrengen..." einde citaat. ' Naar aanleiding van deze laatste zinsnede wil ik een aantal bespiegelingen aan u voorleggen. Ook de verwijzing naar 'bepaalde waarden' en 'verlicht' eigen belang wekt de nodige nieuwsgierigheid. Een en ander komt in deze inaugurele rede aan de orde, zonder overigens het gras voor de WRR weg te maaien.

Maar niet voordat enige begripsverduidelijking wordt geboden. Want 'filantropie' is en blijft in Nederland een moeilijk begrip, omdat het associaties oproept met voorbije tijden, met liefdadigheid. Het huidige filantropie begrip is echter de vertaling van het Engelse woord 'philanthropy' dat in Angelsaksische landen bekend staat als "voluntary action for de public good"; vrijwillige inzet voor het algemeen nut. ${ }^{2}$ Het lijkt daarmee sterk op de Nederlandse begrippen 'particulier initiatief', 'maatschappelijk initiatief' of 'burgerinitiatief'. Wanneer in Angelsaksische landen over de financiering van non-profit organisaties, zoals universiteiten, wordt gesproken is het daar "or government, or market or philanthropy". Filantropie in de huidige betekenis staat kortweg voor de handeling (het geven), voor een inkomstenbron en voor een sector.

De filantropische handeling is de bijdrage in de vorm van geld, goederen en tijd (expertise), vrijwillig ter beschikking gesteld door individuen en organisaties (fondsen, kerken, bedrijven en goede doelenloterijen), waarmee primair algemeen nuttige doelen worden gesteund. ${ }^{3}$ Nederland geeft. $\cup$ bent donateur, of vrijwillige bestuurder van een stichting, $u$ bent vriend van het Museum aan het Vrijthof - of u wordt dat vanmiddag en uw bedrijf sponsort MVV of doet aan werknemersvrijwilligerswerk. Misschien heeft $u$ bij de notaris een goed doel in uw testament laten opnemen of bent u mecenas. Het VU- onderzoek "Geven in Nederland" brengt al 20 jaar het Nederlandse geefgedrag en vrijwilligerswerk in kaart. Nederland is een vrijgevig land.

WRR Werkprogramma 2015. Wetenschappelijk Raad voor het Regeringsbeleid. Den Haag: p. 14 Payton, R.L. (1988). Philanthropy: Voluntary Action for the Public Good. New York: Macmillan Schuyt, Th. (2015). 'Filantropie en de sector filantropie in kort bestek'. In: Bekkers, R., Schuyt, Th. en B. Gouwenberg (red.). Geven in Nederland 2015. Giften, Nalatenschappen, Sponsoring en Vrijwilligerswerk. Amsterdam, Reed Business. pp.31-39. 
Filantropie is goed voor 4.4 miljard euro per jaar; een wetenschappelijk verantwoorde schatting. ${ }^{4}$ Anderen noemen een bedrag van 6 miljard, omdat zij de geschatte jaarlijkse bestedingen van het geschatte totale vermogen van vermogensfondsen erbij rekenen; ${ }^{5}$ tellen wij het onbekende bedrag van nalatenschappen aan kerken en aan lokale nonprofit instellingen, zoals aan ziekenhuizen en aan universiteiten, alsmede de geschatte totale waarde van de loonkosten van vrijwilligerswerk in Nederland van jaarlijks 18 miljard, ${ }^{6}$ dan begrijpt u dat hier serieuze zaken aan de hand zijn. En het wordt nog serieuzer.

Tabel 1. Cijfers Geven in Nederland 2015 ${ }^{7}$

Bronnen van filantropische bijdragen

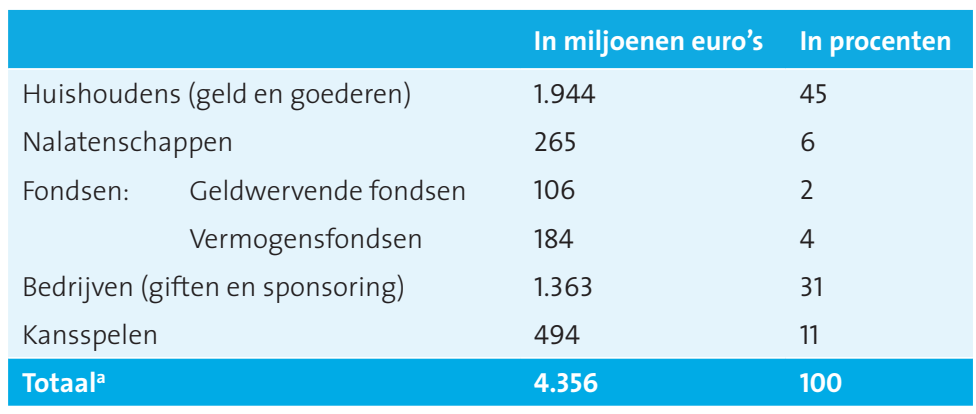

a In verband met afrondingen tellen de percentages niet precies op tot $100 \%$

Filantropie is - ten tweede - een inkomstenbron voor non-profit organisaties. In het project 'Global Civil Society research' is de non-profit sector van 34 landen wereldwijd onderzocht. De inkomstenbronnen voor deze sector worden onderscheiden in:

- charges/fees (eigen inkomsten uit de markt)

- government funding (overheidsfinanciering);

- philanthropy (vrijwillige bijdragen; filantropie) ${ }^{8}$

Binnen Europa is het gemiddelde aan filantropische bijdragen rond de $7 \%$. Nederland staat met $2 \%$ filantropische bijdragen op de laatste plaats. Dat is vreemd. Een vrijgevig land als Nederland geeft (nog) weinig

4 Bekkers, R., Schuyt, Th. en B. Gouwenberg (red.). Geven in Nederland 2015. Giften, Nalatenschappen, Sponsoring en Vrijwilligerswerk. Amsterdam, Reed Business. p. 11

5 Rien van Gendt, geciteerd in de De Dikke Blauwe. Philanthropium jaargids 2014 - 2015. Susteren: Lenthe Publishers. p.22

6 Reactie Nederlandse Organisaties Vrijwilligerswerk op Rapport van Commissie Bakker "Naar een toekomst die werkt" (2008).

7 o.c. zie noot 4., p. 12

8 Salamon, L.M. et al. (2004). Global civil society. Dimensions of the non-profit sector. Bloomfield: Kumarian Press; Burger, A. \& P. Dekker (red.). (2001). Noch markt, noch staat. De Nederlandse non-profitsector in vergelijkend perspectief. Den Haag: SCP 
aan universiteiten, scholen, ziekenhuizen. Hoe dat komt en hoe dat gaat veranderen komt later aan de orde. Terzijde: heeft $u$ al een fonds op naam bij het Universiteitsfonds Limburg, het SWOL; heeft de school waar uw kinderen of kleinkinderen op zitten al een foundation?

Tabel 2. Inkomstenbronnen van non-profitorganisaties in Europa (in procenten)

\begin{tabular}{|c|c|c|c|}
\hline & Eigen inkomsten & $\begin{array}{l}\text { Overheids- } \\
\text { financiering }\end{array}$ & Filantropie \\
\hline Groot-Brittannië & $45 \%$ & $47 \%$ & $9 \%$ \\
\hline Frankrijk & $35 \%$ & $58 \%$ & $8 \%$ \\
\hline Duitsland & $32 \%$ & $64 \%$ & $3 \%$ \\
\hline Nederland & $39 \%$ & $59 \%$ & $2 \%$ \\
\hline België & $19 \%$ & $77 \%$ & $5 \%$ \\
\hline
\end{tabular}

Bron: Salamon, 2004: p. 33; zie noot 8

De sector filantropie - ten derde - wordt vooralsnog gevormd door het samen optrekken van de geldwervende fondsen, zoals KWFKankerbestrijding, de Hartstichting, de Nierstichting en de Koninklijke Nederlandse Redding Maatschappij, van vermogensfondsen zoals het Prins Bernhard Cultuurfonds, het Skanfonds, Adessium - en niet te vergeten de Stichting Elisabeth Strouven - , van lokaal wervende fondsen en van de Kerken. De sector filantropie is sterk in ontwikkeling en tegelijkertijd daarmee moeilijk af te bakenen. ${ }^{9}$ De landelijke koepel Nederlandse Organisaties Vrijwilligerswerk bijvoorbeeld, de NOV, wordt - onterecht - niet vanzelfsprekend tot de sector filantropie gerekend, terwijl dit definitie-technisch wel zou moeten. In Engeland doet men dit wel en spreekt men van de 'charity and voluntary sector'. ${ }^{10}$

Wat is filantropie niet? Het is geen mantelzorg of informele zorg, want dat doet $u$ uit liefde voor uw familie of voor uw vrienden; het is geen buurtcorporatie om gemeenschappelijk zorg of energie in te kopen want dat is uw deelbelang; het is geen participatiesamenleving, want dat begrip vormt de politieke legitimatie van een decentralisatie -, maar vooral bezuinigingsbeleid waarmee familieleden, vrienden en buren onder regie van de lokale overheid worden geacht bij te springen bij de zorg voor hun - maar meestal haar - oude vader of moeder. 
Filantropie daarentegen staat ten diensten van het algemeen nut, in dit geval van zorg voor 'de' ouderen in uw gemeente. Nu zijn bij de decentralisatieplannen van de zorg de lokale filantropische instellingen over het hoofd gezien." Dat komt nog ter sprake.

Terug naar het thema van deze rede: "Filantropie kan dynamiek in sociale systemen aanbrengen...". Omdat deze leerstoel bij de School of Business and Economics, Department Finance is gevestigd en gekoppeld is aan het Network Social Innovation van de Universiteit Maastricht, het NSI, wordt enig 'out of the box' denken toegestaan én verwacht. Voor de vermeende dynamiserende potentie van filantropie gaan wij daarom te rade bij de gezinstherapie. Voor economen en bedrijfskundigen wellicht een onverwachte, maar hopelijk interessante invalshoek.

\section{Systeemtheorie in de gezinstherapie}

Binnen de gezinstherapie bestaat een theoretische richting vertegenwoordigd door onder meer Palazzoli, Watzlawick, Minuchin en Lange ${ }^{12}$ - waarin het gezin wordt opgevat als een sociale systeem en mogelijke problemen alsmede de oplossingen worden geanalyseerd vanuit de systeemtheorie. Hoe brengen deze therapeuten dynamiek in het sociale systeem en kunnen wij van hen iets leren? Een gezinsprobleem wordt volgens de systeemtheorie beschouwd als een ontwikkeld negatief patroon, dat - in veel gevallen - doorbroken kan worden. Problemen ontstaan als het gevolg van de interacties van de gezinsleden. Deze interacties kunnen soms enkele generaties tevoren zijn ingezet. Het gezin ontwikkelt een probleem-veroorzakend patroon, ten gevolge waarvan een of meer gezinsleden problemen krijgen. Veroorzaker van dit probleem is niet één bepaald gezinslid, maar het zijn de regels, het patroon, de structuur van het gezin. Voor de leden van het gezin is dit patroon vanzelfsprekend en daarmee onzichtbaar geworden. De therapeut komt van buiten en zijn of haar rol bestaat hierin, dat hij of zij - als buitenstaander - deze gezin-regels moet ontdekken, om deze vervolgens te veranderen en het gezinssysteem te dynamiseren.

De rol van de buitenstaander, de nieuwkomer is interessant wanneer

11 De Waal, S. (2015). Burgerkracht met Burgermacht. Den Haag: Boom Lemma Uitgevers. p. 125; Schuyt, Th. (2014). 'Nederland is en blijft een filantropisch land' in: De Volkskrant, 19 november, p. 31

12 Palazzoli, M.S. (red). (1979). Paradox en Tegenparadox. Een nieuwe vorm van Gezinsbehandeling. Alphen a/d Rijn: Samsom. Watzlawick, P., J. Helmick Beavin en Jackson, D. (1973). De pragmatische aspecten van de menselijke communicatie. Deventer: Van Loghum Slaterus. Minuchin, S. (1973). Gezinstherapie. Analyse van de gezinsstructuur en gezinsstructuurtherapie. Utrecht/Antwerpen : Het Spectrum. Lange, A. (1985). Gedragsverandering in Gezinnen. Groningen: Wolters-Noordhoff 
het om het doorbreken van vaste patronen gaat ${ }^{13}$. Niet voor niets roept bijna elke organisatie een externe adviseur te hulp als veranderingen nodig zijn of interne problemen niet langer oplosbaar blijken. De organisatieadvieswereld lééft ervan. Wanneer een consultant bij reorganisaties ten tonele verschijnt ontstaat bij de direct betrokkenen gelijk beweging en soms ook onrust. Er gaat iets gebeuren, dat is zeker. "There is a new kid in town" zongen de Eagles al op hun plaat "Hotel California". 14

Over de rol van de buitenstaander heeft Georg Simmel het artikel "The sociological significance of the stranger", "de sociologische betekenis van de vreemdeling" geschreven en daarin werkt hij een aantal intrigerende inzichten uit. ${ }^{15}$ Wanneer de vreemdeling verschijnt ontstaat in het bestaande dynamiek, omdat deze binnentreedt in een omgeving, waartoe hij niet eerder behoorde. De positie van deze nieuwkomer is een speciale want de vreemdeling vertegenwoordigt in de bestaande omgeving een unieke combinatie van dichtbij - én van ver. Dit verwoordt Simmel als volgt: "The union of nearness and remoteness, .... has here produced a system of relations .... which may, in the fewest words, be thus formulated: The distance within the relation signifies that the Near is far: the very fact of being alien, however, that the Far is near". ${ }^{16}$ Door deze speciale positie schrijft Simmel aan de buitenstaander, de nieuwkomer, specifieke sociologische kenmerken toe (er volgen nu letterlijke citaten):

a. Mobiliteit. Vanwege de synthese van nabijheid en afstand kan de vreemdeling met iedereen. ${ }^{17} \mathrm{Hij}$ of $\mathrm{zij}$ is niet gebonden, althans de eerste periode. Dit levert de buitenstaander een tweede kwaliteit;

b. Objectiviteit. "Omdat hij of zij niet is geworteld in de bevooroordeelde tendensen van de groep, staat hij of zij los van alles en vertegenwoordigt het "objectieve".. ${ }^{18}$ Deze neutraliteit, gekoppeld aan beweeglijkheid levert de nieuwkomer weer een kwaliteit, namelijk, die van vertrouwenspersoon;

13 Het volgende is geïnspireerd op het werk van mijn ex-collega en leermeester G.J.F. Leene; zie ook Leene, Gert J.F. and Theo N.M. Schuyt. (2008). The Power of the Stranger. Structures and Dynamics in Social Intervention - A Theoretical Framework. Aldershot/ Burlington: Ashgate

14 De plaat 'Hotel California' van de Eagles uit 1976 bevat het nummer "A new kid in town".

15 Simmel, G. (1921). The sociological significance of the stranger. pp. 322-33 7. In: Park, R. and Burgers, E. Introduction to the Science of Sociology. Chicago: University of Chicago Press

16 o.c. p. 322

17 o.c. p. $323-32$

18 o.c. p. 324 
c. Vertrouweling. Citaat: "Dat maakt de vreemdeling tot vertrouweling; de meest verrassende onthullingen en bekentenissen vallen hem of haar ten deel. ${ }^{19}$ Tenslotte bezit de vreemdeling;

d. Vrijheid van conventie: de vreemdeling is niet aan de bestaande regels gebonden; hij of zij is de vrijere persoon, praktisch en theoretisch. ${ }^{20}$

Deze schets van de specifieke positie en kwaliteiten van de buitenstaander c.q. vreemdeling lijkt wonderwel ook van toepassing op de werkwijze van de hiervoor genoemde systeemtheoretische gezinstherapie. De therapeut treedt als buitenstaander het problematische systeem binnen en daarmee is - in principe - de mogelijkheid tot verandering geschapen. Om dit te bereiken wisselt de therapeut op een deskundige wijze van positie: "Afwisselend voegt hij of zij zich in en maakt zich weer los". ${ }^{21}$ Het veranderen wordt gestimuleerd doordat de therapeut op een speciale wijze met sociale afstand omgaat: hij is inderdaad tegelijkertijd dichtbij en veraf. Hij heeft buiten het problematische systeem overleg met collegae met wie hij strategieën bedenkt, terwijl hij ook iemand "van binnen" wordt door zich in te leven. Van der Hart en Rubinstein vatten, in navolging van Haley, therapie op "als een strategisch of tactisch 'spel', waarin de therapeut door bepaalde (tegen)zetten het gedragspatroon van zijn cliënten probeert te doorbreken, teneinde het ontstaan van nieuw, adequaat gedrag mogelijk te maken".22 Omdat het gezin er alles aan zal doen de gezin-regels te handhaven, wordt - bewust of onbewust - gepoogd de therapeut in hun 'spel' te betrekken. De manier om aan deze druk te ontkomen is het bewaren van afstand, het inzetten van deskundigheid en een relatief zelfstandige positie. 'Relatief', omdat een therapeut in de regel op verzoek van het probleemgezin optreedt en daarvoor contractuele afspraken worden gemaakt. Want als het problematische gezin na een aantal sessies afziet van verdere behandeling is de rol van de therapeut per definitie uitgespeeld.

"Waar gaat dit heen?" zult u zich afvragen. Welnu, vermogensfondsen hebben vrij geld en zijn in hoge mate zelfstandig. Anheier en Leat betogen dat fondsen "are among the freest institutions in modern societies: free in the sense of being independent of market forces and the popular political will. This enables them to ignore political, disciplinary and professional boundaries, if they choose, and to take risks

\footnotetext{
19 o.c. p. 324

20 o.c. p. $324-325$

21 Minuchin (1973):162; zie noot 12

22 Hart, O. van der en Rubinstein, T. (1980). "Strategische en tactische aspecten van therapie". pp. 71-87. In: K. van der Velden. Directive therapie 1. Deventer: Van Loghum, Slaterus. Haley, J. (1971). Changing Families: A Family therapy Reader. New York: Grune and Stratton. p. 71
} 
and consider approaches others cannot". ${ }^{23}$

Fondsen kunnen - indien nodig - snel ingrijpen, zoals de Stichting Bijzondere Noden in Rotterdam - het geld staat dezelfde dag op de rekening van de familie in nood - of de Wellcome Trust in Londen dat met voorrang het onderzoek naar het Ebola medicijn financierde. Vermogensfondsen bedenken alternatieven voor de maatschappij, zoals de Weekend School dat kansarme jongeren extra steun geeft, de gezamenlijke ouderenfondsen die innovatieve culturele producties voor en door ouderen, het internationale "Living live Arts", stimuleren, het Fonds 1818 in Den Haag dat buurtbibliotheken opzet, het Oranjefonds dat 'NL doet' een groot succes maakt, het Prins Bernhard Cultuurfonds dat een magneetwerking heeft voor particulieren om een 'Fonds op naam' te maken, Van Harte Resto's en ook 'Stadsgoud' van de Stichting Elisabeth Strouven dat burgerinitiatieven uitlokt. Waarschijnlijk zal mede door de toegekende stimuleringspremie van 'Stadsgoud' ook de tot op heden verduisterde parel van Maastricht - de Servaasbrug - binnenkort in de avonden worden aangelicht. Niet voor niets heeft het Directoraat Generaal Research and Innovation van de Europese Commissie een grootschalig onderzoek naar de foundations in de Europese Unie laten uitvoeren om zicht te krijgen op de bijdragen van deze fondsen aan de vernieuwing van de Europese kenniseconomie. ${ }^{24}$ Bepaalde fondsen durven zelfs op de rand van het politiek toelaatbare te opereren, zoals de Start Foundation dat de boetes voor de stages van kinderen van illegalen voor zijn rekening nam. Overigens is dat binnen de filantropie niet uniek; zie de rol van kerkgenootschappen bij de opvang van uitgeprocedeerde asielzoekers.

Samenvattend; wat valt van de systeemleer uit de gezinstherapie te leren? Het dynamiseren van sociale systemen kan in principe wanneer een buitenstaander ten tonele verschijnt, die binnen het bestaande systeem relatief zelfstandig is, én beweeglijk, én met een eigen deskundigheid.

a. Relatieve zelfstandigheid

b. Bewegelijkheid

c. Eigen deskundigheid

Wij verhogen het niveau - van analyse wel te verstaan - en richten ons op de huidige sector filantropie.

23 Anheier, H. and Leat, D. (2006). Creative Philanthropy. London: Routledge, geciteerd in: Anheier, H.K. and S. Daly (eds.) (2007). The Politics of Foundations. A comparative analysis_London: Routledge, p.4 


\section{Herintrede van een sector}

Filantropie is van alle tijden. ${ }^{25}$ Lang geleden was het armenzorg, zorg voor weduwen en wezen, maar ook gezondheidszorg. Neem het bekende "Hospices de Beaune" dat uit de $15^{\mathrm{e}}$ eeuw dateert. Religieuzen zetten zich in voor de minder bedeelden, maar deden ook aan onderwijs. Zij zorgden voor een "revolving fund" door de exploitatie van wijngaarden (Domain du Moulin aux Moines) dat richting Meursault ligt. De geestelijkheid vond aan haar zijde particulieren. Neem de historie van de huidige Hermitage aan de Amstel, het voormalige Amstelhof. De rijke Amsterdamse koopman Helleman liet in 1680 een vermogen na aan de Diaconie. Deze besloot een huis voor "oude besjes" te stichten. "Tot die tijd werden hulpbehoevende vrouwen opgevangen door particulieren: duur en inefficiënt. De stad schonk een stuk grond en de bouw kon beginnen". ${ }^{26}$ De huidige Hermitage zou er niet geweest zijn als de goede doelenloterijen financieel niet waren bijgesprongen. En dicht bij huis: ook de verbouwing van het Museum aan het Vrijthof zou zonder filantropische bijdragen niet mogelijk zijn geweest.

Een ander sprekend voorbeeld is niet zo bekend: Madurodam in Den Haag. Opgericht door de bankiers familie Maduro om hun zoon George te gedenken die in WOII in Nederland in het verzet is omgekomen. Bij binnenkomst van Madurodam treft de bezoeker een miniatuur aan van zijn geboortehuis in Willemstad. De familie heeft deze mini-stad aan Den Haag geschonken; het is commercieel als non-profit opgezet; het dient een educatief doel omdat scholieren het "gemeentebestuur" vormen en de winst wordt uitgekeerd aan culturele doelen in Den Haag. Madurodam kan ook anno 2015 als voorbeeld van innovatie gelden.

Met de uitbouw van de verzorgingsstaat in de tweede helft van de $20^{e}$ eeuw is de overheid de financiering van veel algemene voorzieningen gaan overnemen. Daarmee verdween voor particulieren de noodzaak om zelf financieel bij te dragen, maar erger nog, de betrokkenheid bij die voorzieningen verminderde daarmee ook sterk. Zoals God verdween uit Jorwerd, zo verdween de particuliere financiering uit scholen, universiteiten, ziekenhuizen, musea, dorpshuizen, uit het jeugdwerk en de armenzorg. Maatschappelijk draagvlak was niet langer leidend en nodig. Filantropie - de vrijwillige bijdragen aan algemeen nuttige voorzieningen - verdween naar de marge.

25 Het hier volgende is eerder deels door mij gepubliceerd in De Dikke Blauwe 2014 (zie noot 5) 'Een beknopte geschiedenis van de filantropie in Nederland' pp. 96-99 
Dit proces van overheidsfinanciering van particuliere non-profit instellingen stoelde op het politieke uitgangspunt 'wie betaalt, bepaalt'. Deze volledige financiering geschiedde evenwel volgens de 'mal' van het toenmalige, verzuilde, particulier initiatief. Als de overheid protestantschristelijke non-profit instellingen begunstigde, werden - en moesten - tegelijkertijd ook de katholieke en openbare hetzelfde ontvangen. Door dit evenredigheidsprincipe werd deze wijze van overheidsfinanciering van 'particulier initiatief' een vermenigvuldigingsfactor, de zogenaamde "verdriedubbelaar". Om deze reden kreeg Nederland de grootste nonprofit sector van de wereld. ${ }^{27}$ Maar wel een met een uniek karakter: een sector van 'staatsparticulier initiatief'. ${ }^{28}$ Politiek draagvlak nam de leiding over van maatschappelijk draagvlak. Dit mag mede een verklaring zijn voor de eerder vermelde schijnbare paradox dat Nederland een vrijgevig land is, terwijl non-profit organisaties zeer beperkt filantropische inkomsten kennen.

Maar vanaf ongeveer 1993, - voor alle duidelijkheid: in een tijd dat van bezuinigingen en ander overheidsbeleid nog geen enkele sprake was - deed filantropisch Nederland van zich spreken en ook ontwikkelden zich autonoom, van onderop nieuwe vormen van filantropische betrokkenheid. Een trend van "Do it yourself" brak door. Particuliere fondsen op naam, familiefondsen, (lokale) geldwervende fondsen schoten als paddenstoelen uit de grond en namen rap in aantal en omvang toe. Een sector filantropie deed haar herintrede en begon aan een niet te stuiten opmars.

Al in 1988 richtten de vermogensfondsen in Nederland een eigen brancheorganisatie op, de Vereniging van Fondsen in Nederland, de FIN. In 1989 begon Novamedia met de loterijen voor het goede doel, waarvan de Nationale Postcode Loterij de bekendste is. In 1994 werd de VFI, de Vereniging van Fondsenwervende Instellingen opgericht; in 1994 ook het NGF, het Nederlands Genootschap van Fondsenwervers. In datzelfde jaar kwam het Instituut voor Sponsoring en Fondsenwerving, het huidige Instituut Fondsenwerving, het IF, tot stand. Gestart door een geneesheer directeur van het Canisius Ziekenhuis te Nijmegen, drs. Maerten Verstegen. ${ }^{29,30}$ Die had in die tijd, door de recovery room - de uitslaapkamer - in zijn ziekenhuis te laten sponsoren door het bekende Limburgse biermerk Brand naar collega ziekenhuisdirecteuren heel wat uit te leggen (u begrijpt dat dit een fictief voorbeeld is).

27 Salamon, L. M. et.al. (eds.). (2004). Global Civil Society: Dimensions of the Nonprofit Sector. Volume 2 (Vol. 2). Baltimore: Johns Hopkins University, p.19

28 Waal, S. De. (2000). Nieuwe strategieën voor het publieke domein. Alphen a/d Rijn: Samsom

29 Verstegen, M. (2014). Handboek Fondsenwerving. Peize: Tekst en Uitleg BV

3o Westen, H. van der. (2013). Handboek sponsoring en fondsenwerving. Zutphen: Walburg Pers 
Maar KWFkankerbestrijding bestond toch al sinds 1949? En het Juliana Welzijns fonds, nu Oranjefonds sinds 1948? En het Nationaal archief voor het inzamelingswezen, nu het Centraal Bureau Fondsenwerving, sinds 1925? Klopt allemaal, maar de goede doelen stonden aan de rand. Een beetje op zichzelf en in zichzelf gekeerd, zeker waar het de vermogensfondsen betrof. Het was een en al uitbouw van de verzorgingsstaat en overheid.

In 1994 regelden de directeur van het toenmalige Juliana Welzijnsfonds (nu Oranjefonds), Hans Hillenius en de toenmalige directeur van het Prins Bernhard Cultuur Fonds, Jan Herman Meerdink bij de FIN-leden geld om onderzoek naar de totale omvang van de goede doelen te starten. Het VU onderzoek "Geven in Nederland" was geboren. Daarvoor waren bezoeken afgelegd aan het "Center for the Study of Philanthropy" in Indianapolis, waar het "Giving USA" onderzoek werd - en wordt uitgevoerd. Het eerste boek 'Geven in Nederland' verscheen in 1997. De Verenigde Staten en Nederland zijn overigens tot vandaag de enige twee landen in de wereld waar macro-economisch onderzoek naar het totaal van de filantropische bijdragen wordt verricht. In Europe is Nederland het enige land en ook het enige Europese land met drie universiteiten met leerstoelen filantropie: de Vrije Universiteit, de Erasmus Universiteit en nu de Universiteit Maastricht. Een goede uitvalsbasis om binnen Europa op dit terrein gidsland te worden; met het exporteren van de onderzoekexpertise van "Geven in Nederland" om binnen Europa te komen tot een "Giving Europe" is - onder andere met hulp van de Nationale Postcodeloterij - een krachtig begin gemaakt.

Mede onder druk van de media, onder invloed van rellen, ontstond voor de sector filantropie de noodzaak tot meer externe verantwoording naar het publiek. Verkeerde berichtgevingen van Foster Parents Plan, de ruzie tussen de Eurocollecte en Coins for Care (twee inzamelingsacties van het losse muntgeld bij de invoering van de euro ten behoeve van goede doelen) - een kleine anekdote: ik heb dat jaar in de Maastrichtse Carnavalsoptocht meegelopen met een collectebus gemaakt door mijn carnavalsvriend Ronald met het opschrift: "Coins vur Beer" - het salaris van de Hartstichting directeur. De strijkstok werd een topic. De goede doelen stelden commissies in en codes en richtlijnen werden ontwikkeld. Zo kwam er een Commissie Herkströter over de hoogte van het eigen vermogen van geldwervende fondsen, later gevolgd door de commissie Post. Er kwam een code Wijffels. 
De vernieuwing van de successiewet (de Commissie Moltmaker) bracht vermogensfondsen rond 2000 vele malen in vergadering bijeen. Vaak werden deze bijeenkomsten georganiseerd door bankiers die zich graag als gastheer en beoogd vermogensbeheerder presenteerden. In november 2002 werd op de VU een congres gehouden over het onderwerp en met de titel: "Naar een Nederlandse Raad voor de Filantropie". Het was een brug te ver. Toch werd in 2006 tijdens het Civil Society congres de geboorte van de Samenwerkende Brancheorganisaties Filantropie aangekondigd, de SBF.

Bij het afscheid van de directeur van KWFKankerbestrijding, jhr. Dr. K.W. van der Poll, 31 mei 2002, was de titel van het symposium "Visie gevraagd' en droeg een van de bijdragen de titel "Filantropie: maatschappelijk onmisbaar, politiek onzichtbaar". Daarin kwam echter snel verandering.

In 2002 namelijk deed de overheid (het toenmalige Ministerie van Justitie) in het kader van de "antiterrorismebestrijding" een check bij de sector filantropie. Men was bang dat verkeerd geld via fondsen bij verkeerde doelen terecht zou komen. Dat bleek niet het geval te zijn. Later raakte de overheid meer inhoudelijk geïnteresseerd en ging het belang van de sector inzien. Beleidsadviezen werden gevraagd. De Taskforce van het Innovatieplatform "Geven voor Weten" werd in 2004 ingesteld en bracht in 2007 advies uit. Universiteiten moesten zich ook op filantropische inkomsten gaan richten. In 2008 zette de Europese Commissie een groot onderzoek uit naar "University Fundraising"; allemaal ter versterking van de kenniseconomie en de concurrentiekracht van Europa. In 2012 gevolgd door het reeds genoemde onderzoek onder foundations, de EUFORI-study.

De Nederlandse overheid raakt meer en meer geïnteresseerd in de filantropie. Een lobby vanuit de SBF met het filantropie coördinerende Ministerie van Veiligheid en Justitie, en het ministerie van Algemene Zaken leidt ertoe dat op 21 juni 2011 het Kabinet een "Convenant met de sector filantropie" sluit, met als titel "Ruimte voor geven". Filantropie en de sector zijn bij beleidsmakers in Den Haag doorgedrongen. Het project "Filantropie" van de Wetenschappelijke Raad voor het Regeringsbeleid, waarmee deze oratie aanving, zal zeker in positieve zin aan deze bewustwording bijdragen. Het onafhankelijke filantropisch particulier initiatief is terug; een maatschappelijke sector heeft - onder een andere naam - zijn herintrede gedaan. Maar is daarmee de werkelijkheid voldoende op begrip gebracht? 


\section{Maatschappelijke onduidelijkheid}

De oratie aan de VU in 2001 van de eerste leerstoelhouder filantropie had als titel: "De filantropische sector en filantropische studies in Nederland: wetenschappelijke aandacht voor een maatschappelijke sector in wording". ${ }^{31}$ Dat is veertien jaar geleden. Hoe is het met het wordingsproces? Kan men wel spreken van een sector? Is de onwetendheid over - en het ongemak met deze termen niet een gevolg, een artefact, van een algemene maatschappelijke onduidelijkheid? Áls dat zo mocht zijn, naar wie moet dan gekeken worden en hoe dat op te lossen? (Denkt u daarbij nog even terug aan de systeemtheorie van de gezinstherapie; er is geen schuldige; het patroon is de veroorzaker)

Wie zijn bij sectorvorming de interacterende actoren? Wie maken het patroon? Neen, we kijken niet gelijk richting overheid, want als filantropie staat voor particuliere vrijwillige inzet voor het algemeen nut, dan los je als zelfstandige sector - ook al ben je in wording - dit probleem van de onduidelijkheid eerst zelf maar op.

Wie is woordvoerder/ster voor deze sector in Nederland? Eind achttiende, begin negentiende eeuw was er de Maatschappij tot Nut van het Algemeen, met Nieuwenhuijzen Kruseman als een voor de voortrekkers, halverwege de twintigste eeuw kende Nederland tot 1989 de Nationale Raad voor het Maatschappelijk Welzijn met als woordvoerder Damoiseaux. Deze koepel vertegenwoordigde het particulier initiatief in Nederland. Maar wie verschijnt er in beeld als heel Nederland over de organisatievergoeding van Coen van Veenendaal van Alpes d'Huzes valt? Niemand. ledereen in de sector "duikt" merkte het vakblad "Philanthropium" minzaam op. Niemand durfde en durft nog steeds hardop te zeggen dat geldwerven geld kost en niemand verklaart in het openbaar dat een groot gezondheidsfonds dat jaarlijks tientallen miljoenen euro's aan onderzoeksprojecten uitkeert niet geleid kan worden door een vrijwilliger met een onkostenvergoeding, maar door een professional die naar behoren dient te worden betaald. Geen topsalarissen - daar hebben wij in Nederland andere sectoren voor maar een redelijk salaris, hetgeen iedereen, - ook de donateur aan de deur - zal begrijpen. Kortom, aan de zichtbaarheid, aan de uitleg wat en hoe de sector is - en werkt, aan de communicatie, valt het nodige te doen. 
Een heldere missie en een visie zou ook niet verkeerd zijn. Duidelijk en met één mond. Als sector verwijzen naar 'het goede doel' of naar de bijdragen aan het algemeen nut zet niet veel zoden aan de dijk. De initiator van de studie van de filantropie in de Verenigde Staten, Bob Payton ziet, samen met zijn leerling Moody, voor filantropie een fundamentele rol weggelegd, die in democratieën belangrijk is. "We have argued that philanthropy plays an essential role in defining, advocating and achieving the public good.... Both government and philanthropy provide public goods. Sometimes they do so in partnership - government money is a primary source of funding for non-profit organizations - and other times philanthropy steps in to provide public goods ....... when both the market and government fail to do so".32 Zij vervolgen: "Democracy needs philanthropy because democracy is not simply a political phenomenon'.33 Zie hier een inhoudelijke legitimatie van filantropie dat naast politieke democratie er ook sociale - of basisdemocratie bestaat, dat ten principale verschilt van overheidsbeleid dat stoelt op politieke democratie. De vele burgerinitiatieven van vandaag; de vele acties van fondsen ondersteunen de analyse van deze collega-onderzoekers uit de Verenigde Staten. Deze particuliere initiatieven dragen bij aan de pluriformiteit 34 van onze maatschappij en bieden tegenwicht aan 'gulzig bestuur'.35 Dit laatste begrip wordt zo nader uitgelegd.

Een andere belangrijk "to do" item voor de sector filantropie zijn opleidingen. Om een fonds (vermogens- of geldwervend) te beginnen is het oprichten van een vereniging of stichting een eerste vereiste. Als fiscale facilitering wordt gewenst is het aanvragen van een ANBI of SBBI status ${ }^{36}$ vereist; voor het verkrijgen van vertrouwen is een keurmerk, zoals onder andere van het Centraal Bureau Fondsenwerving aan te bevelen waardoor de stichting zich onderwerpt aan toezicht. Het toezicht zal het vertrouwen in de sector verhogen. Dat is zeker waar, maar ook een halve waarheid. Want voor diegenen die willen gaan werken in de sector filantropie bestaat geen specifieke opleidingsverplichting. Als u op een operatietafel ligt dan is het natuurlijk belangrijk dat er een Inspectie voor de Volksgezondheid bestaat, maar voor $\mathrm{u}$ is het - lijkt mij - prettiger te weten dat de bewuste chirurg een uitstekende vakvrouw of vakman

32 Payton, R.L. en M.P. Moody. (2008). Understanding Philanthropy. Its Meaning and Mission, Bloomington and Indianapolis: Indiana University Press. p. 156.

33 R.L. Payton en M.P. Moody, o.c. p. 157.

34 Prewitt, K. (1999). 'The importance of foundations in an open society' In: Strübin, M. and P. Walkehorst (eds). The Future of Foundations in an Open Society. Gütersloh: Bertelsmann Foundation Publ. pp. 1729. ; Koele, I.A. (2007). International Taxation of Philanthropy. Dissertatie Universiteit Utrecht. P.68 Voor de uitleg van het begrip 'Gulzig Bestuur': zie noot 39 
is met een gedegen opleiding. Het is, met andere woorden, moeilijker om een taxivergunning voor Maastricht en omstreken te krijgen dan om fondsenwerver of fondsenbesteder (ook dit woord bestaat nog niet in het Nederlands; het is de vertaling van 'grantmaker') bij een grote filantropische instelling te worden.

We stappen over naar de andere interacterende patroonveroorzaker, de overheid. Als voorbeeld, eerder beloofd, moge gelden het decentralisatiebeleid in dezorg. Dezegrote operatiegaat begrijpelijkerwijs met veel discussie gepaard. Het gaat te snel; gemeenten zijn niet toegerust, zorg-verlenende instellingen moeten wachten tot budgets bekend zijn en verkeren evenals de zorgafhankelijken in onzekerheid. Het blijkt niet eenvoudig om deze giga-operatie als maatwerk politiek aan te prijzen, terwijl er ook drastisch bezuinigd wordt. Alle betrokken partijen houden niet op deze pijnpunten aan elkaar duidelijk te maken. Over deze zaken handelt het hier niet.

Er ontbreekt namelijk één partij in de zorgdiscussie en wel het lokale particulier initiatief. ${ }^{37}$ Dat zijn onder meer de kerken, de lokale maatschappelijke organisaties, fondsen, het maatschappelijk betrokken bedrijfsleven, service-clubs, burgerinitiatieven, vrijwilligersorganisaties, voedselbanken, buurtzorgcorporaties, lokale gemeenschapsfondsen, om een willekeurig aantal uit dit brede scala van vrijwillige inzet te schetsen. En als deze groep wel wordt opgemerkt en aangesproken gebeurt dat vaak zonder de eigenheid van dit particulier initiatief te respecteren. De vele vrijwilligers worden gezien als onbetaalde arbeidsreserve voor een bezuinigende overheid en particuliere fondsen op hun beurt worden snel gezien als welkome aanvulling op de krimpende gemeentelijke budgets ${ }^{38}$. Het lokale politieke systeem zal er verder - wij wijzen weer even terug naar de gezinstherapie - alles aan doen om deze relatieve buitenstaanders in hun "politieke spel" te betrekken.

Het Ministerie van VWS bedoelt met particulier echter wat anders. Het spreekt namelijk over "particuliere verantwoordelijkheid". U, als burger, als gehandicapte wordt als particulier benaderd om het maatwerk van de overheid mogelijk te maken. Natuurlijk is er niets mis mee wanneer de eigen verantwoordelijkheid wordt benadrukt. Ook is het vanzelfsprekend dat $u$ voor uw naaste familie zorgt. Maar het gaat niet goed als

37 Het hiervolgende is deels eerder gepubliceerd; Schuyt, zie noot 11

38 Schuyt, Th. en E.E. Mariani (red.).( 2014). Manifest "Er waart een golf van idealisme door Nederland".

Amsterdam: VU, FSW, Werkgroep Filantropische Studies 
ambtenaren bij $u$ als zorgbehoevende thuiskomen om te inventariseren wat $u$ zelf, uw partner, kinderen, vrienden, vriendinnen, buren voor uw zorgbehoefte kunnen betekenen als daarbij de mogelijkheden en motivaties niet voldoende worden gerespecteerd. Uw informele netwerk wordt dan onderdeel gemaakt van overheidsbeleid. Professor Willem Trommel spreekt in dit verband - hier komt het zojuist genoemde begrip - van "Gulzig bestuur".39 Citaat: "Het afgelopen decennium is in de wereld van politiek, beleid en bestuur een opmerkelijke ontwikkeling op gang gekomen. Terwijl in brede kring het geloof in maatschappelijke maakbaarheid achterhaald is verklaard, zien we een bestuur dat zich steeds indringender met de leefwereld van burgers bemoeit: achter de voordeur, in de wijken, op de arbeidsmarkt, in de vrije tijd. Bijzonder daarbij is ook dat maatschappelijke organisaties, marktpartijen en ook burgers zelf medeverantwoordelijk worden gemaakt voor de uitvoering van alsmaar meer bestuurstaken. Dit alles vormt aanleiding om van gulzig bestuur te spreken, ofwel bestuur dat erop gericht is burgers en organisaties tot grotere trouw en toewijding aan de publieke zaak te bewegen".

Hoe pakt het "maatwerk" van de zorg in de praktijk uit? Er wordt door de gemeente een afweging gemaakt wat de overheid voor $u$ kan doen en wat uzelf en uw informele netwerk aankan. Maar er is - en was - in Nederland meer onder de zon dan de dualistische keuze tussen overheid en individu doet voorkomen. Nederland kent een derde partij, het maatschappelijk filantropisch particulier initiatief dat zich vroeger en nu bekommerde om mensen, om de gemeenschap. Particulier initiatief is niet hetzelfde als mantelzorg, of de steun van familie- of informele netwerken. Particulier initiatief is de Cirkelbus uit Voorschoten waar 80 vrijwilligers met busjes voor een klein bedrag ouderen vervoeren; ouderen die zij voorheen niet kennen.

Deze maatschappelijke partij ontbreekt in de decentralisatie van de zorg. De gemeenten - en de door haar gebudgetteerde zorginstellingen zitten aan de keukentafel van de zorgbehoevende. Maar de gemeenten zitten niet aan tafel met het lokale particulier initiatief. Dat is de ontbrekende partij. Toen ik aan de Vrije Universiteit "Sociologie van de Hulpverlening" 40 studeerde was er aan de Prins Hendriklaan in Amsterdam de Raad voor Overleg en Advies (ROA) gevestigd. Een platform van het burgerlijk en kerkelijk particulier initiatief dat met elkaar

39 Trommel, W. (2009). Gulzig bestuur. Oratie, Vrije Universiteit, 17 sept. 2009. Meppel: Uitgeverij Boom 
en periodiek met de gemeentelijke overheid overleg voerde over sociale kwesties in Amsterdam. Hoe daklozen op te vangen; de buurthuizen, ongehuwde moeders, de wijkopbouw, enz. Het particulier initiatief had eigen projecten, prioriteiten en doelstellingen. De gemeentelijke overheid de hare. Men overlegde en onderhandelde. Wat kunnen we samen doen; waar zijn we het niet met elkaar eens?

De Waal trekt de analyse van de ontbrekende partij veel breder dan de sector filantropie. In zijn boek 'Burgerkracht met Burgermacht' doet hij gewag van "een wonderlijke leemte in de huidige publieke en politieke oriëntatie op de fundamentele ombouw van de verzorgings- en verzekeringsstaat. Enerzijds wordt daarin ingezet op actief burgerschap als nieuw paradigma ..... anderzijds worden de bestaande private nonprofit organisaties in het publieke domein ...... volstrekt genegeerd". ${ }^{41}$

Samenvattend: de maatschappelijke onduidelijkheid rond de sector filantropie is systeemtheoretisch toe te schrijven aan het interactiespel tussen een afwisselend negerende dan wel gulzige overheid en een zich te weinig zelfbewust presenterende - zeg maar onvolwassen sector filantropie. Hoogleraar Sigrid Hemels geeft beiden een volgend opvoedingsadvies: "De politici moeten loslaten. Het is net als bij ouders met kinderen die het huis uitgaan en op eigen benen willen staan. De ambtenaren zijn niet de schuldigen. Wat nu gebeurt is een politieke invulling van het begrip 'algemeen nut'. Dat mag niet. De houding ten aanzien van particulier initiatief is er een van georganiseerde angst; men gaat bij voorbaat uit van misbruik". De tijd is gekomen voor een nieuwe slogan, met als centraal begrip "onafhankelijkheidsacceptatie".

$\mathrm{Na}$ de periode van de uitbouw van de verzorgingsstaat is - toen de bezuinigingen nodig waren - met de kabinetten Lubbers (1982 - 1994) de "markt" als redmiddel omarmd. In 1994- 1998 vertaalde de overheid dit marktdenken in de MDW-operatie: Marktwerking, Deregulering en Wetgevingskwaliteit. De tijd is gekomen voor een nieuwe slogan, met als centraal begrip "Onafhankelijkheidsacceptatie. Het overheidsbeleid voor 2014 - 2018 zou gestoeld moeten zijn op een DWG beleid: Draagvlakverbreding, Wetgevende facilitering en Governance". ${ }^{2}$

41 Waal, S.P.M. de. (2015). Burgerkracht met Burgermacht. Den Haag: Boom Lemma Uitgevers. p. 125

42 Interview met Sigrid Hemels 15 juli 2013; in: het Manifest, p. 19; zie noot 38 


\section{Diversificatie met behoud van verschillen in compliance}

Het genoemde interactiespel past in een nog wijdere context van diversificatie en draagvlakverbreding. Nieuwe partijen komen in actie - bedrijven, burgers, fondsen, informele netwerken - en voegen zich in - en bij - bestaande arrangementen. Natuurlijk zorgen kinderen voor zorgbehoeftige ouders. En vriendinnen voor elkaar. Maar dan moet het vanuit haarzelf komen en niet opgelegd worden. En ze moeten het wel kunnen zowel qua deskundigheid als qua tijd. Professor Marjolein Broese wees in haar oratie "Informele zorg 3.0" op de beperkingen van informele steun. Zij stelde onder meer: "Daarbij veranderen onze familiestructuren: willen kleinkinderen van 40 zorgen voor hun grootouders van 95 als hun ouders van 70 dat niet meer kunnen?"43

Deze diversificatie vraagt de nodige voorzichtigheid. Familie- en vriendenbanden kennen een andere intrinsieke logica dan bijvoorbeeld door de overheid geboden professionele zorg. Net zoals een bedrijf weer andere dominante waarden kent. Menselijke interacties in kleine groepen zoals families, in commerciële organisaties zoals bedrijven, in filantropische organisaties zoals goede doelen en kerken, maar ook in het overheidsvoorzieningenstelsel van rechten en plichten deze menselijke interacties zijn consistent in de wijze waarop met elkaar wordt omgegaan en in de dominante motivatie óm erin te participeren. Een voorbeeld mag dit duidelijk maken: als $u$ genodigd bent bij vrienden te gaan eten, verwacht $u$ niet bij het weggaan een rekening en pinautomaat onder uw neus te krijgen. Tenminste dat is niet te hopen. Een ander voorbeeld van de reeds genoemde Cirkelbus: deze vrijwilligersorganisatie, opgericht voor ouderenvervoer werd door de wethouder gebeld of zij in verband met de bezuinigingen ook gehandicapten wilden gaan vervoeren. Dan is het opletten geblazen.

In fundamenteel interdisciplinair wetenschappelijk onderzoek naar coördinatiemechanismen in organisatie- en samenlevingsvormen is een basismodel van menselijke acties en coördinatie ontwikkeld. 44,45 Dit model is ontleend aan - en kan worden toegepast in onder meer organisatiewetenschappen, bestuurskunde, sociale psychologie, economie,

43 Broese van Groenou, M.I. (2012). Informele zorg 3.0. Schuivende panelen en een krakend fundament. Oratie Amsterdam: Vrije Universiteit, 28 juni

44 Hegner, F (1986). Solidarity and hierarchy: institutional arrangements for the coordination of actions. In F. X. Kaufmann, G. Majone, \& V. Ostrom (eds.). Guidance, Control en Evaluation in the Public Sector. The Bielefeld Interdisciplinary Project, De Gruyter, Berlijn/New York.

45 Kaufmann, F. X. (1987). Prevention and Intervention in the analytical Perspective of Guidance. In KI. Hurrelman, F. X. Kaufmann, \& F. Lösel (eds.), Social Intervention: Potential and Constraints (pp. 17-18). De Gruyter, Berlijn/New York. 
bedrijfskunde en sociologie. Omdat het geldingskracht heeft op zowel micro - meso- als macro niveau, biedt het mogelijkheden de maatschappelijke rol van de sector filantropie inzichtelijk te maken.

"In order to explain the coordination of actions, there is a multitude of approaches in the social sciences whose systematization, however, which can be briefly described as follows:

\begin{tabular}{|l|l|l|}
\hline Mode of Coordination & Type of Transaction & Reasons for Compliance \\
\hline Hierarchy & power relation & fear \\
\hline Market & Exchange & interest \\
\hline Norms and Values & conformity and approval & commitment \\
\hline Solidarity & personal relationship & sympathy trust \\
\hline
\end{tabular}

Vertaald naar de Nederlandse situatie levert dit model het volgende beeld op: overheid, markt en filantropie zijn naast familie en informele netwerken - allocatiemechanismen voor het bereiken van algemeen nuttige doelen. Vreemd genoeg is gebleken dat dominantie van een van deze mechanismen niet tot een vrolijke samenleving leidt. Een dominant informeel familie - en netwerkmodel laten wij hier buiten beschouwing, maar zou leiden tot vriendjespolitiek en nepotisme. Een overheersend overheidsregime leidt tot bureaucratie en tot ontmoediging van persoonlijke verantwoordelijkheid. De markt daarentegen vergroot die persoonlijke verantwoordelijkheid en vrijheid, maar leidt als dominerend mechanisme tot onacceptabele bestaansonzekerheid en wijdverbreide armoede. Als filantropie zou overheersen, zou de persoonlijke betrokkenheid voorop worden gesteld, maar dit mechanisme kan leiden tot willekeur en ongelijkheid. Een oplossing voor de toekomst ligt misschien in een gebalanceerd samenspel van deze mechanismen, waarin de overheid een sterke basis van voorzieningen garandeert en de markt en de sector filantropie ruimte creëren voor dynamiek en pluriformiteit. Een dergelijke opzet sluit enerzijds aan bij de geschiedenis van Europese democratieën doordat het de principes van de Franse Revolutie doet herleven: vrijheid (markt), gelijkheid (overheid) en broederschap (filantropie). Deze opzet past anderzijds bij de overgang van Europese verzorgingsstaten naar een civil society waarin meer aandacht wordt besteed aan de bijdragen en verantwoordelijkheden van individuele burgers, maatschappelijke 
organisaties en het bedrijfsleven. ${ }^{46}$

Wat betekent dit concreet voor zowel de overheid als de sector filantropie? In ieder geval huiswerk voor beiden. Aan overheidszijde wordt kennis van - en respect voor het specifieke en de zelfstandigheid van de sector filantropie gevraagd. Aan sectorzijde is het vergroten van zichtbaarheid en herkenbaarheid aan de orde, oftewel profilering en professionalisering. Voor beide geldt het advies: "elkaar kennen, elkaar ontmoeten en waar mogelijk elkaar versterken. 47

Hoe moet dat in zijn werk gaan? Met de opgedane kennis uit de gezinstherapie weten wij nu dat het werken met contracten aan te bevelen is als een relatieve buitenstaander aan tafel schuift. Contracten zorgen voor een nieuwe dynamiek in relaties en zetten de deur open voor nieuwe ideeën en innovatie. Daarnaast is een contract flexibel. Het geldt voor een vastgestelde periode, levert extra aandacht en energie op en, bovenal, het geeft de betrokken partijen legitimiteit.

Met het convenant "Ruimte voor Geven" sloot de Nederlandse overheid een herenakkoord dat eenzelfde status heeft als een contract. Beide partijen beloven open tegen elkaar te zijn in het nastreven van publieke doelen en elkaars onafhankelijkheid te accepteren op basis van wederzijds respect en eerlijkheid. De overheid garandeert dat er geen 'substitutie' zal plaatsvinden: met andere woorden, als er vanuit de sector filantropie geld beschikbaar komt voor een bepaald doel, zal de overheid zich niet terugtrekken door op dit doel te bezuinigen. 'Substitutie' werd en wordt in de sector als het belangrijkste obstakel voor samenwerking gezien.

Een contract biedt overheden tegelijkertijd ook de mogelijkheid af te rekenen met buitensporige vormen van willekeur. Met het uitwisselen van informatie en het voeren van onderhandelingen wordt de weg vrijgemaakt voor een afspraak die het algemeen belang dient: 'Wij betalen dit, als jullie dat doen'. Als er na een dergelijke afspraak toch nog sprake is van willekeur, kan de overheid altijd nog haar wettelijke macht uitoefenen en verklaren dat de filantropische bijdrage 'niet bijdraagt aan het algemeen belang' en de fiscale voordelen intrekken. Contractuele afspraken zijn niet alleen voordelig voor de betrokken partijen, maar dragen ook bij aan minder overregulering en bureaucratie.

46 Schuyt, Th. (2012). 'Filantropie in Europese Verzorgingsstaten; een uitdagende belofte?'. In: Openbaar Bestuur 22, 5, pp. 2-10

47 Gouwenberg, B. (2010). Natuurbehoud en de sector filantropie in Nederland. Den Haag: Ministerie van LNV. p. 10 


\section{The economics of philanthropy}

Waarschijnlijk hebben de hier aanwezige collega's en studenten van de School of Business en Economics onderhand het gevoel gekregen dat ze bij de verkeerde oratie zijn aangeschoven. In dit tweede deel hoort $u$ hopelijk meer van uw gading. Filantropie omvat niet alleen het geven van tijd, maar ook - en vooral - het geven van geld en goederen. Het Centraal Bureau van de Statistiek spreekt van "transacties om niet". Het aantal particulieren dat een eigen filantropisch fonds opricht stijgt de afgelopen 20 jaar exponentieel, niet alleen in Nederland maar in de hele Europese Unie. Er is heel veel geld buiten de overheid. Nederland is nog nooit zo rijk geweest. Wrang genoeg ongelijk verdeeld en die ongelijkheid groeit met de armoede.

Tabel 3. EUFORI STUDY stijging fondsen (hoewel alleen R\&I) ${ }^{48}$

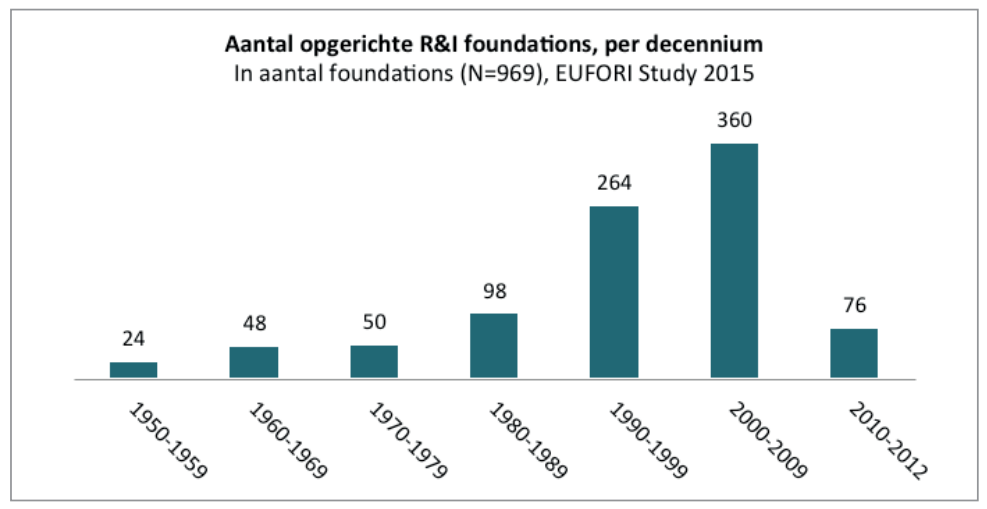

Economen van het Social Welfare Research Institute in Boston hebben geprobeerd een schatting te maken van de hoeveelheid vermogen dat er in de komende vijftig jaar in de VS aan volgende generaties zal worden doorgegeven. De schattingen variëren van 41 duizend miljard dollar tot 136 duizend miljard dollar. Zij verwachten bovendien dat de erflaters niet alles aan hun kinderen of de staat zullen nalaten, want in veel gevallen zitten hun kinderen er behoorlijk warmpjes bij, en levert doneren aan 'goede doelen' talloze belasting- en andere voordelen op. Dit is waarom zij spreken van de 'Golden Age of Philanthropy'.49, 50

48 EC-DG R\&I (2015). Euforistudy, Synthesis report. P. 42

49 Havens, J.J. en P.G. Schervish, (1999), Millionaires and the Millennium: New Estimates of the Forthcoming Wealth Transfer and the Prospects for a Golden Age of Philanthropy Paper. Boston: Social Welfare Research Institute Boston College

50 Havens, J.J. en P.G. Schervish, (2003), 'Why the $\$ 41$ trillion wealth transfer estimate is still valid: a review of challenges and questions' Journal of Gift Planning, 7 (1) 11-15; 47-50. 
Ook in Nederland heeft Bekkers op basis van CBS data een extrapolatie gemaakt van de nalatenschappen ten gunste van maatschappelijke doelen in de komende jaren. ${ }^{51}$ Deze schatting is conservatief omdat de toename van het aantal kinderloze Nederlanders dat gaat overlijden er nog niet in verwerkt is.

\section{Tabel 4. Geschatte nalatenschappen aan algemeen nuttige doelen ${ }^{52}$}

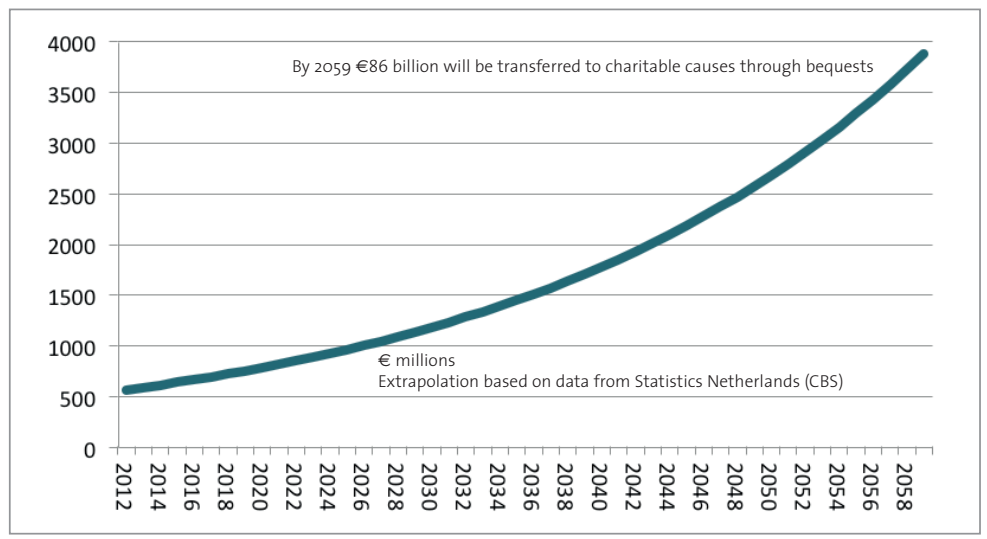

\section{De Gouden Eeuw van de Filantropie}

De komende jaren wordt er een gestage groei verwacht in filantropische bijdragen aan het algemeen nut. Als we alleen naar de VS en WestEuropa kijken, welke factoren kunnen deze 'filantropische opleving' verklaren?

De eerste factor is van economische aard. De geïndustrialiseerde wereld is rijk, al is de rijkdom ongelijk verdeeld. De naoorlogse generatie in deze landen is welvarend geworden en geeft haar geld door aan de volgende generatie. Een algemene welvaartsstijging is dus een belangrijke voorwaarde voor filantropie. De tweede factor is demografisch. Veel landen met een welvarende naoorlogse generatie worstelen met de problemen van een snel vergrijzende bevolking. Tegelijkertijd worden de gezinnen steeds kleiner. Dus wordt er meer geld aan minder kinderen nagelaten. Ouderen zonder kinderen zorgen voor $98 \%$ voor alle nalatenschappen ten gunste van goede doelen.53 Daarnaast blijkt leeftijd zelf een belangrijke factor voor het geefgedrag

\footnotetext{
Bekkers, R. (2013). De maatschappelijke betekenis van filantropie. Amsterdam: Vrije Universiteit, Oratie, p.18 o.c.

Volgens Henk de Graaf. Centrum Nalatenschappen Den Bosch
} 
van mensen.54,55 De derde factor is sociaal-cultureel en politiek. Mensen hechten meer waarde aan zingeving en betekenisgeving. Met als gevolg een toegenomen bewustzijn van burgerschap in geïndustrialiseerde samenlevingen, een grotere zelfstandigheid (samenhangend met een hoger onderwijsniveau), en een gevoel van onafhankelijkheid. Filantropie past in deze trend van "Do it Yourself".

\section{Hunting the major donors}

Alle grote banken in Nederland hebben recentelijk "Charity Desks" toegevoegd aan hun private banking afdelingen. Vermogensfondsen bieden particulieren de mogelijkheid bij hen een fonds op naam te vestigen. Alle grote geldwervende fondsen hebben een "major donor" afdeling. Voor de High Networth Individuals (HNWI's) vermogenden is er namelijk een economische reden, jawel een economische reden om filantroop te worden of een filantropische foundation te stichten. Het advies dat zij van hun vermogensbeheerder krijgen luidt kortweg als volgt: "als u uw hele vermogen van tientallen, honderden miljoenen aan uw kinderen geeft, dan wordt dat binnen één generatie besteed aan echtscheidingsadvocaten, Ferrari's en heroïne. Het beste dat wij u vanuit economisch standpunt kunnen adviseren is het stichten van een "Family Foundation", because it keeps the family together". Anders kunt u uw geld beter uit het raam gooien.

De universiteiten, inclusief de Universiteit Maastricht blijven niet achter en werpen zich op de alumni. De European University Association pleit voor 'diversification of income streams'. Maar aantrekken van filantropische inkomsten door kennisinstituten staat in Nederland en de EU nog in de kinderschoenen. Dit blijkt onder meer uit het onderzoek 'Giving in Evidence'. ${ }^{6} \mathrm{Er}$ is nog een lange weg te gaan.

\section{Hoed u voor de liefdadigen}

Is het nu allemaal rozengeur en maneschijn in de filantropie? Neen, vanzelfsprekend niet. Ook de filantropie kent mooie en minder mooie kanten en het is de taak en plicht van wetenschap een kritische wetenschap te zijn. Het eerste boek dat ik in 1993 onder andere over filantropie schreef had als titel "Hoed u voor de liefdadigen". 57 Het is

54 Geven in Nederland (2015), p. 19 ; zie noot 4

55 Midlarsky, E. and E. Kahana, (1994), Altruism in Later Life. Londen: Sage Publication

56 Breeze, B., Wilkinson, I., Schuyt, Th.N.M., Gouwenberg, B.M., (2011). Giving in Evidence. Fundraising from philanthropy for research funding in European universities. Brussels: EC. Directorate General Research. $177 \mathrm{p}$.

57 Schuyt, Th. (1993). Hoed u voor de liefdadigen. Een boek voor altruïsten, filantropen, vrijwilligers, sponsors, professionele hulpverleners, ontwikkelingswerkers en hun cliënten. Houten/Zaventem: Bohn Stafleu Van Loghum 
gelukkig allang uitverkocht anders had ik hier niet gestaan. Volgens de WRR, geciteerd aan het begin van deze rede, wordt filantropie ook "geïnspireerd door bepaalde waarden of 'verlicht' eigenbelang. Enkele voorbeelden mogen dit laatste illustreren. De Ford Foundation werd begin 1936 door Henri en Edsel Ford opgericht, gelijk toen bekend werd dat hun privé aandelenbezit door Roosevelt zwaar zou worden belast in verband met de New Deal ter bestrijding van de grote depressie..$^{58}$

Maastricht kent één rechtstreekse verbinding met het noorden en wel via Amsterdam naar Alkmaar. In die stad staat het AZ stadion, gerealiseerd door Dirk Scheringa. Deze voormalige filantroop is groot geworden door leningen met kleine lettertjes en aanvullende verzekeringsproducten te verkopen aan met name die groepen die niet bijzonder alert waren op die kleine lettertjes. Toen het stadion was voltooid was het gevuld met diezelfde groep die Dirk luid toejuichte. De historicus Thomas Adam geeft in zijn boek 'Philanthropy, Patronage and Civil Society' een verklaring hoe dit kan. 59 Volgens hem is filantropie een 'transformatie-mechanisme' waarmee rijkdom en geld kan worden omgezet in andere waarden die in de maatschappij belangrijk worden geacht. Hij geeft het voorbeeld van de Vanderbilts in de Verenigde Staten; steenrijk geworden met het aanleggen van spoorwegen, nouveau riche, maar niet geaccepteerd door de heersende knickerbocker elite. Tot het moment dat zij mecenas werden van de Metropolitan Opera en het Metropolitan Museum. Dat maakte hen welkome gasten. Het je inzetten voor het algemeen nut kan heel wat aanzien en reputationele 'bijvangst' opleveren. Collega Bekkers constateert - op basis van onderzoek - tevens dat je er ook knap gezond van blijft. ${ }^{60}$

\section{'Bepaalde waarden': de 'philanthropy-scale' ${ }^{61}$}

Om welke 'bepaalde waarden' - door de WRR genoemd - gaat het in de filantropie? Veel nalatenschappen in Nederland gaan naar KWFKankerbestrijding. Vaak geschonken door particulieren van wie de partner aan kanker is overleden. Aan economen is dit mooie gebaar moeilijk uit te leggen, want de betrokken persoon raakt immers een aanzienlijk deel van het vermogen kwijt, terwijl hij of zij daarmee de partner niet de volgende ochtend - per postorderbedrijf - terugbezorgd krijgt. Het motief om te schenken zal zijn "om deze ziekte - chronisch of niet - de wereld uit te helpen". Waarom dragen zoveel Nederlanders

58 Sutton, F.X. (1987). The Ford Foundation: The Early Years. pp. 41-91. In: Daedalus. Journal of the American Academy of Arts and Sciences, 116,1.

59 Adam, Th. (ed.) (2004). Philanthropy, Patronage and Civil Society. Bloomington: Indiana University Press

60 Bekkers, R. pp 55-56. zie noot 51.

61 Zie: Schuyt, Th, R. Bekkers and J. Smit (2010). 'The Philanthropy Scale: a sociological perspective in measuring new forms of Pro social Behaviour' In: Social Work and Society, Vol 8. 
bij aan internationale hulpacties, terwijl zij die getroffen bevolking niet kennen?. Waarom zetten zoveel mensen zich in voor behoud van het regenwoud, van bedreigde diersoorten terwijl zij er zelf nooit mee van doen zullen hebben? Filantropische doelen zijn doelen die de hele maatschappij aangaan, het zijn algemeen nuttige doelen, belangrijk voor het overleven van de huidige en volgende generaties. Het behoud van een historisch kerkgebouw, waar bijvoorbeeld de Stichting Behoud en Herbestemming Religieus Erfgoed zich voor inzet - een gift aan 'ALS' heeft het doel de overlevingskansen van de menselijke soort - sociaal, cultureel en ecologisch - te vergroten. Dat is een waarde die essentieel is en als zodanig door iedereen wordt herkend én erkend. Voor het gemak noem ik dat het 'Mandela effect': na zoveel jaren gevangenis niet oproepen tot haat en wraak; maar pogen blank en zwart te verzoenen. Dat wordt gezien als het mooiste dat een mens kan betekenen voor de maatschappij.

Over dat betekenen zegt Akkermans: "het gaat bij particulier initiatief om de beleving van rechtvaardigheid en betrokkenheid. Juist die betrokkenheid heeft niet alleen maatschappelijke betekenis, maar ook voor de personen zelf. .... Zie het onderzoek onder slachtoffers, bij mensen bijvoorbeeld die een kind door een ongeval hebben verloren. Empirisch onderzoek wijst uit dat die slachtoffers zich vooral druk maken "dat het niet nog een keer kan gebeuren; dat het gevaarlijke verkeersplein veranderd moet worden". Bij fouten in het ziekenhuis zie je dit ook terug: de betrokkenheid dat voorkomen wordt dat missers nogmaals worden gemaakt. Elk individu verwoordt het op zijn eigen manier; het gemeenschappelijke zit erin dat mensen betekenis willen geven. ${ }^{62}$

In de definitie van filantropie wordt gesteld dat "primair het algemeen nut" wordt gediend. Veel Nederlanders geven in stilte; anderen schreeuwen het van de daken. Eigenbelang en algemeen belang vormen een continuüm. Eigenbelang is niet hetzelfde als egoïsme. Eigenbelang kent ook vele vormen. Als $u$ - volledig anoniem - uw totale vermogen weggeeft aan een goed doel, dan zult u zichzelf geen slecht mens vinden. Of het moet zijn dat $u$ ongelooflijk veel goed te maken heeft. In dat geval is uw schenking een psychologische pleister op uw lage zelfwaardering. 
Energie inzetten voor de maatschappij is een niet gemakkelijke, maar wel een uitdagende en in ieder geval een zeer prestigieuze bezigheid. Niemand zal na zijn/haar dood herdacht worden als "rijk gestorven". Hij/ zij zal wel herdacht worden als degene die een ziekenhuis heeft gesticht, een museum heeft geholpen of de kenniseconomie heeft bevorderd. Dat is het ultieme dat mensen tijdens leven kunnen realiseren. Filantropie biedt daar de mogelijkheid toe.

Wellicht begint dit alles 'prekerig' te klinken, maar dan moet $u$ ook niet in een kerk gaan zitten.

Samenvattend: de markt van de filantropie is ook voor economen een interessante markt, waarbij moet worden aangetekend dat niet alles filantropisch goud is wat er blinkt.

\section{Naar een geronto-filantropie.}

Door vergrijzing is het vraagstuk van de ouderen in veel West Europese landen een beleidsmatig, politiek, en maatschappelijk issue geworden. De verwachte toename van de behoefte aan verzorging van de oudere mens heeft hier mede aan bijgedragen. Met als gevolg dat in wetenschappen die zich met veroudering bezighouden de aandacht voor de afname van gezondheid overheerst. Veel gerontologisch onderzoek is medisch van aard; zie de studies naar Alzheimer, dementie en andere psychische en/ of lichamelijke problemen. Geriatrie is een specialisatie geworden. Ook binnen een sub-discipline van de gerontologie, de sociale gerontologie, waarin de sociale en maatschappelijke aspecten van het ouder worden bestudeerd, lijkt de aandacht rond ziekte en achteruitgang dominant; zie de studies naar eenzaamheid en informele netwerkzorg.

De focus op deze aspecten van het ouder worden kent binnen deze wetenschappen ook een positieve variant, namelijk door de aandacht te vestigen op "succesfull aging". Hier wordt studie gemaakt hoe ouderen gezond en vitaal kunnen blijven. Bewegen, hersengymnastiek, gezonde voeding en een stimulerende omgeving blijken bij te dragen aan minder zorggebruik. Ook val- en struikel onderzoek van bewegingswetenschappers past in dit kader. "Succesfull aging" lijkt in deze zin de positieve formulering van het "burden-paradigma": de ouderen hebben het zelf in handen om zo lang mogelijk gezond te blijven en geen last te worden. Ondanks deze positieve formulering domineren zowel in de gerontologie, geriatrie als in de sociale gerontologie de invalshoek van care en burden. 
Maar zijn het niet ook - en vooral - de ouderen die de 'Gouden eeuw van de filantropie' vormgeven en gaan vormgeven? Juist ouderen geven aanzienlijke sommen gelds aan maatschappelijke doelen en deze financiële overdrachten nemen snel in betekenis toe. Ook besteden ouderen veel tijd aan maatschappelijke doelen.

De kombinatie filantropie en ouderen is zowel voor economen - specifiek voor 'finance'-onderzoekers - als binnen het gerontologische onderzoek innovatief en leidt tot een nieuw begrip en onderzoeksrichting: de studie van de 'geronto-filantropie'. Welke ouderen vormen de pijlers van de verwachte "Gouden eeuw van de filantropie". Wat bepaalt of ouderen geven of blijven geven? Zijn dat sociale factoren, psychische- , fysiologische, biochemische factoren of is het een combinatie? Welke ouderen geven en welke niet of zijn het van plan? Deze - en andere vragen staan in deze onderzoeksrichting centraal. Ik hoor de private bankers en charity desk officers de oren al spitsen.

De titel van deze rede luidt: "Philanthropie Dynamique; over de sociologische betekenis van de herintrede van een sector"; hoe kan deze verhandeling kort worden samengevat?

Het Nederlandse particulier initiatief is er altijd geweest en vertegenwoordigt een historisch gegroeide "asset" in dit land:63 zet drie Nederlanders bij elkaar en je hebt een stichting, wordt wel gezegd. Nederland kent het grootste aantal stichtingen en verenigingen per hoofd van de bevolking.

Filantropie en de sector filantropie maken daar deel van uit. Deze sector laat voorzichtig weer van zich horen en wordt langzaam zichtbaar in het debat over de toekomst van de verzorgingsstaat. Dat debat - politiek, bestuurlijk en beleidsmatig is jarenlang gedomineerd door de discussie "of overheid of markt". Maar nu krijgt de overheid ook aandacht voor - en herontdekt de sector filantropie. Daarmee herleeft de angst voor BBB, de bestuurlijke en beleidsmatige bruikbaarheid van de burger, door Trommel "gulzig bestuur" genoemd. De politieke democratie kan gaan overheersen. De sector filantropie heeft - mede door haar specifieke drijfveren, compliance en uiting gevend aan vormen van directe, sociale democratie de potentie hier een eigen geluid en visie naar voren te brengen. Door de terugkeer vanuit haar maatschappelijke marge-positie heeft zij het voordeel én de potentie - als relatieve buitenstaander

63 Rooy, P. de. (2014). Ons stipje op de waereldkaart. Amsterdam: Uitgeverij Wereldbibliotheek. 
bestaande maatschappelijke arrangementen te dynamiseren, zonder dat ik het maatschappelijk 'gewicht' van deze groeiende sector wil overschatten.

Op basis van systeemtheorie is betoogd dat de sector filantropie door haar relatieve zelfstandigheid, bewegelijkheid, eigen financiële middelen ( en haar expertise (en tijd) hierbij een dynamiserende en innovatieve rol kan spelen. Daarmee wordt balans gebracht in de diversificatie van de verzorgingsstaat van de toekomst: naast een belangrijke overheid - die zich kan verstaan met zelfverantwoordelijk informele netwerken -, een krachtige markt ook een zelfbewuste, volwassen sector filantropie.

\section{Werkplan voor de leerstoel}

De reden tot het instellen van deze bijzondere leerstoel door de Stichting Elisabeth Strouven is de wens van het bestuur en de Raad van Toezicht om in het huidige tijdsgewricht haar rol van filantropisch particulier fonds opnieuw te definiëren. De aanleiding vormde de uitnodiging tot het schrijven van een Lustrumboek met als opdracht "Het verrichten van wetenschappelijk onderzoek naar de afgelopen 50 jaar Stichting Elisabeth Strouven. Op basis van bovengenoemde studie formuleren van opties van een duurzaam giftenbeleid" Aan het lustrumboek wordt hard gewerkt samen met onderzoekster en high potential Carlijn Postma. Begin oktober zal het worden gepubliceerd.

Eerder al, in 2005, hadden wij (collega's Gouwenberg, Mariani en ik) op verzoek van de toenmalige bestuurssecretaris - en helaas overleden ir. Jan Meijers - een onderzoek naar het vermogens- en giftenbeleid van de Stichting afgerond. ${ }^{6}$

Daarnaast zal de leerstoel bijdragen aan het Limburgse en Maastrichtse fondsenoverleg, met speciale aandacht voor een mogelijke doorstart van het Maastrichtfonds. Ook is een taak het creëren van een leeromgeving, waarmee recentelijk een aanvang is gemaakt door het samenbrengen van experts en de leiders van Nederlandse Dansdagen, het Masterplan Filmtalent Limburg en de buitenplaats Vaeshartelt.

Doel is het mee uiting geven aan de ontwikkelingen van onderop; het zelf doen door burgers, fondsen, kerken en bedrijven; in een strategie van alliantie, zoals het bestuur van de Stichting Elisabeth Strouven voor ogen staat.

64 Gouwenberg, B., Mariani , E., Schuyt, Th. (2004). Beleidsnotitie Stichting Elisabeth Strouven. Amsterdam: Vrije Universiteit, FSW, Werkgroep Filantropie 
Deze leerstoel is gevestigd aan de School of Business and Economics, Department Finance en is verbonden aan het Network Social Innovation. De financiering wordt de eerste jaren door de Stichting verzorgd. Een bijzondere leerstoel heeft echter duurzaam effect - en de Stichting wil graag naar een duurzaam giftenbeleid - als de leerstoel deel gaat uitmaken van het reguliere universitaire onderzoek. De Afdeling Finance van de School of Business and Economics doet onderzoek naar pensioenen en vermogenden. Daar is een kans om - samen met hen - de nieuwe onderzoekslijn van de geronto-filantropie te ontwikkelen. De geronto-filantropie is een kansrijke niche, in welk onderzoek zal worden samengewerkt met de collega's van het VU onderzoek 'Geven in Nederland' - van de 'Longitudinal Aging Study Amsterdam', van het $\mathrm{VU}$ onderzoek onder vermogenden en van het NESDA onderzoek (Nederlands onderzoek naar Depressie en Angst).

Het Netwerk Social Innovation is een voorbeeld van 'science in society'; het direct samenwerken met economische, maatschappelijke en culturele partners in de regio. De eerste Denktank - bijeenkomst met hen heeft al plaatsgevonden. Kansen liggen er ook in de onderwijssfeer, bijvoorbeeld samen met de Universiteit van Hasselt.

Op termijn zou ook in Maastricht een centrum kunnen ontstaan, zoals het VU Center for Philanthropic Studies in Amsterdam en het Erasmus Center for Strategic Philanthropy in Rotterdam. Met betrekking tot die centers attendeerde mijn vorig jaar overleden erudiete vriend Jan Snelleman mij op de Huizinga lezing van Stefan Themerson. Citaat: "Moeten we niet een Leerstoel in Fatsoen instellen aan onze Universiteiten? Een Leerstoel in de Fysica van het Fatsoen en in de Moleculaire Chemie der Zachtheid? Een Vakgroep Altruïsme? Een Faculteit der Vriendelijkheid?"65

\section{Dankwoord}

Geachte directeur en bestuurssecretaris, voorzitter en leden van de Raad van Toezicht van de Stichting Elisabeth Strouven, beste Dik, Theo en Arie, dank voor deze uitdagende opdracht. Het past in deze tijd dat fondsen en kennisinstituten meer samenwerken. Milienne, dank voor alle vrolijkheid, steun en inzet. Voor diegenen die het niet weten: de organist vandaag is Theo van Ballegooy, bestuurssecretaris van de Stichting Strouven; voorwaar een fonds waar muziek in zit. Zangeres Ingrid, dank voor het prachtige Ave Maria!

65 Themerson, S. (1982). Een leerstoel in fatsoen. Huizinga-lezing 1981. Amsterdam: Atheneum, Polak en Van Gennep. p. 52-53. 
Universiteit, geachte decaan Philip Vergauwen, dank voor de gastvrije ontvangst. Afdelingshoofd en collega's bij Finance: wat een enthousiaste ondernemende afdeling! Jaap, Piet, Rob, Paul, Harry; het voelt alsof ik opnieuw ga studeren in Maastricht. Niet te vergeten dank aan Francien, Carina, Cecille en Els. De sfeer op een secretariaat blijkt een goede graadmeter voor hoe het met een afdeling is gesteld. Meer dan uitstekend dus.

Het Netwerk Social Innovation (NSI): Andries: met Paul Iske en zijn nieuwe internationale instituut voor Serieuze Opmontering en met mijn doelstelling om gezamenlijk op studiereis te gaan naar de filantropen ${ }^{66}$ zal aan innovatie in het netwerk geen gebrek zijn.

Studenten, collega's, belangstellenden, gemeente Maastricht, fondsen, bedrijven, maatschappelijke organisaties, non-profit organisaties en kerken: met $u$ allen wil ik de komende jaren graag samenwerken om 'science in society' invulling te geven.

Oud burgemeester Houben, toen op 16 september 2004 het bestuur van het net opgerichte Maastrichtfonds met onder ander Alex Reinders, Fernand Jadoul, Jan Voorvelt, Reinier Thissen en ik het nieuwe fonds in het Bonnefanten museum presenteerden, had $\mathrm{u}$ mij in een uitvoerige advies brief van 29 september 2003 onder meer de volgende raad gegeven: "De oprichting van een gemeenschapsfonds staat en valt bij een goede en zeer doordachte voorbereiding, waarvoor de nodige tijd genomen moet worden". Ik heb uw advies ter harte genomen: het is juni 2015 .

Oud collega Gert Leene, zoals je hebt gehoord, heb ik veel van je geleerd. Huidige collega's van het Center for Philanthropic Studies VU; dank, we kunnen nog jaren vooruit; nu drie Nederlandse universiteiten filantropieonderzoek kennen gaan wij gezamenlijk voor het Giving Europe onderzoek, voor Nederland als filantropisch gidsland, voor het door ons opgerichte European Research Network on Philanthropy (ERNOP), ${ }^{67}$ voor het filantropiecongres tijdens het Nederlandse EU voorzitterschap 2016 en voor de organisatie van het grote internationale filantropie congres in 2018 in Amsterdam. Alle hier aanwezige VU collega's, jullie aanwezigheid stel ik zeer op prijs. Ook het Jansmagenootschap mag niet onvermeld blijven. Prachtig dat jullie hier zijn.

66 Ontleend aan de speech van Ivo de Wijs, 23 mei 2001, in de Aula Vrije Universiteit, ter gelegenheid van de oratie van de eerste leerstoelhouder filantropie

67 www.ernop.eu 
In de cortège liep mijn oud - collega, emerita hoogleraar Jacqueline de Savornin Lohman mee. Jouw strafrechtproefschrift, Jacqueline, vele jaren geleden, droeg als titel "Kwaad dat mag". Het is daarom niet verwonderlijk dat je nu de oudste cabaretière van Nederland bent. Ik hoop dat ik jou ook aan het lachen heb gekregen. Collega prof. Geert Sanders, hartelijk dank voor je steun en enthousiasme.

Familieleden Termote, Weitkamp en Dekkers, vriendinnen en vrienden van Monique, zussen en broers Schuyt, familieleden Schuyt, vrienden en vriendinnen, dank dat jullie met zovelen naar Maastricht zijn gekomen. Schoonvader Termote, 95 jaar, zelfstandig wonend, internist, kan vandaag niet hier zijn; daarom wordt hij vervangen door Ria en Kikki. Dank daarvoor.

\section{Michiel en Monique}

Onze zoon Michiel is voor zijn studie Geneeskunde,'honours programme', op stage in Pisa. Hij blijft vandaag direct verbonden omdat zijn beste vriend Tom opnamen van deze oratie nu naar hem doorstuurt. Zoon, succes daar, groeten aan je medestudenten! Je moeder en ik zijn trots op je!

Toen ik veertig was en alles relationeel mij erg onzeker toescheen, heb ik - op aanraden van mijn vriend Leo - door een beroemde waarzegster uit Amsterdam mij de toekomst laten voorspellen. "Ik zou een sterke vrouw tegenkomen, uit Limburg, met de voorletter M." Dat is uitgekomen.

Lieve Monique uit Venray, drie jaar later ontmoetten wij elkaar, trouwden en kregen Michiel. We hebben al heel veel moois beleefd, met z'n tweeën én met z'n drieën. Ik hoop dat er nog veel mag volgen. Dank voor je onvoorwaardelijke liefde en inhoudelijke steun. Aan jullie twee draag ik deze oratie op.

Ik heb gezegd. 


\section{Literatuur}

Adam, Th. (ed.) (2004). Philanthropy, Patronage and Civil Society. Bloomington: Indiana University Press

Anheier, H. and Leat, D. (2006). Creative Philanthropy. London: Routledge

Anheier, H.K. and S. Daly (eds.) (2007). The Politics of Foundations. A comparative analysis London: Routledge

Bekkers, R. (2013). De maatschappelijke betekenis van filantropie. Amsterdam: Vrije Universiteit, Oratie

Bekkers, R., Schuyt, Th. en B. Gouwenberg (red.). Geven in Nederland 2015. Giften, Nalatenschappen, Sponsoring en Vrijwilligerswerk. Amsterdam, Reed Business

Berg, H. van den. (1963). Sociologie van de Hulpverlening, Boom, Meppel

Breeze, B., Wilkinson, I., Schuyt, Th.N.M., Gouwenberg, B.M., (2011). Giving in Evidence. Fundraising from philanthropy for research funding in European universities. Brussels: EC. Directorate General Research

Broese van Groenou, M.I. (2012). Informele zorg 3.0. Schuivende panelen en een krakend fundament. Oratie Amsterdam: Vrije Universiteit

Burger, A. \& P. Dekker (red.). (2001). Noch markt, noch staat. De Nederlandse non-profitsector in vergelijkend perspectief. Den Haag: SCP

De Dikke Blauwe. Philanthropium jaargids 2014 - 2015. Susteren: Lenthe Publisher

EC-DG R\&I (2015). Euforistudy, Synthesis report

Gouwenberg, B., Mariani , E., Schuyt, Th. (2004). Beleidsnotitie Stichting Elisabeth Strouven. Amsterdam: Vrije Universiteit, FSW, Werkgroep Filantropie

Gouwenberg, B. (2010). Natuurbehoud en de sector filantropie in Nederland. Den Haag: Ministerie van LNV 
Haley, J. (1971). Changing Families: A Family therapy Reader. New York: Grune and Stratton.

Hart, O. van der en Rubinstein, T. (1980). "Strategische en tactische aspecten van therapie". pp. 71-87. In: K. van der Velden. Directive therapie 1. Deventer: Van Loghum Slaterus

Havens, J.J. en P.G. Schervish, (1999). Millionaires and the Millennium: New Estimates of the Forthcoming Wealth Transfer and the Prospects for a Golden Age of Philanthropy Paper. Boston: Social Welfare Research Institute Boston College

Havens, J.J. en P.G. Schervish, (2003). 'Why the $\$ 41$ trillion wealth transfer estimate is still valid: a review of challenges and questions' Journal of Gift Planning, 7 (1) 11-15; 47-50.

Hegner, F (1986). Solidarity and hierarchy: institutional arrangements for the coordination of actions. In F. X. Kaufmann, G. Majone, \& V. Ostrom (eds.). Guidance, Control en Evaluation in the Public Sector. The Bielefeld Interdisciplinary Project, De Gruyter, Berlijn/New York

Kaufmann, F. X. (1987). Prevention and Intervention in the analytical Perspective of Guidance. In KI. Hurrelman, F.X. Kaufmann, \& F. Lösel (eds.), Social Intervention: Potential and Constraints (pp. 17-18). De Gruyter, Berlijn/New York

Koele, I.A. (2007). International Taxation of Philanthropy. Dissertatie Universiteit Utrecht

Lange, A. (1985). Gedragsverandering in Gezinnen. Groningen: WoltersNoordhoff

Leene, Gert J.F. and Theo N.M. Schuyt. (2008). The Power of the Stranger. Structures and Dynamics in Social Intervention - A Theoretical Framework. Aldershot/ Burlington: Asghate

Midlarsky, E. and E. Kahana, (1994). Altruism in Later Life. Londen: Sage Publications

Minuchin, S. (1973). Gezinstherapie. Analyse van de gezinsstructuur en gezinsstructuurtherapie. Utrecht/Antwerpen: Het Spectrum 
Palazzoli, M.S. (red). (1979). Paradox en Tegenparadox. Een nieuwe vorm van Gezinsbehandeling. Alphen a/d Rijn: Samsom

Payton, R.L. (1988). Philanthropy: Voluntary Action for the Public Good. New York: Macmillan

Payton, R.L. and M.P. Moody. (2008). Understanding Philanthropy. Its Meaning and Mission, Bloomington and Indianapolis: Indiana University Press

Prewitt, K. (1999). 'The importance of foundations in an open society' In: Strübin, M. and P. Walkehorst (eds). The Future of Foundations in an Open Society. Gütersloh: Bertelsmann Foundation Publ. pp. 17-29

Rooy, P. de. (2014). Ons stipje op de waereldkaart. Amsterdam: Uitgeverij Wereldbibliotheek

Salamon, L. M. et.al. (eds.). (2004). Global Civil Society: Dimensions of the Nonprofit Sector. Volume 2 (Vol. 2). Baltimore: Johns Hopkins University; Salamon, L.M. et al. (2004). Global civil society. Dimensions of the non-profit sector. Bloomfield: Kumarian Press

Schuyt, Th. (1993). Hoed u voor de liefdadigen. Een boek voor altruïsten, filantropen, vrijwilligers, sponsors, professionele hulpverleners, ontwikkelingswerkers en hun cliënten. Houten/Zaventem: Bohn Stafleu Van Loghum

Schuyt, Th. (2001). De Filantropische Sector en Filantropische Studies in Nederland; Wetenschappelijke belangstelling voor een maatschappelijke sector in wording. Houten/Diegem: Bohn Stafleu Van Loghum

Schuyt, Th, R. Bekkers and J. Smit (2010). 'The Philanthropy Scale: a sociological perspective in measuring new forms of Pro social Behaviour' In: Social Work and Society, Vol 8.

Schuyt, Th. (2012). 'Filantropie in Europese Verzorgingsstaten; een uitdagende belofte?'. In: Openbaar Bestuur 22, 5, pp. 2-10

Schuyt, Th. (2013). Philanthropy and the Philanthropy Sector: an Introduction. The Rediscovery of an Income source for the Public Good. Farnham/ Burlington: Ashgate/ Gower 
Schuyt, Th. en E.E. Mariani (red.).( 2014). Manifest "Er waart een golf van idealisme door Nederland". Amsterdam: VU, FSW, Werkgroep Filantropische Studies

Schuyt, Th. (2015). 'Filantropie en de sector filantropie in kort bestek'. In: Bekkers, R., Schuyt, Th. en B. Gouwenberg (red.). Geven in Nederland 2015. Giften, Nalatenschappen, Sponsoring en Vrijwilligerswerk. Amsterdam, Reed Business. pp.31-39.

Simmel, G. (1921). The sociological significance of the stranger. pp. 322-337. In: Park, R. and Burgers, E. Introduction to the Science of Sociology. Chicago: University of Chicago Press

Sutton, F.X. (1987). The Ford Foundation: The Early Years. pp. 41-91. In: Daedalus. Journal of the American Academy of Arts and Sciences, 116,1.

Themerson, S. (1982). Een leerstoel in fatsoen. Huizinga-lezing 1981. Amsterdam: Atheneum, Polak en Van Gennep

Trommel, W. (2009). Gulzig bestuur. Oratie, Vrije Universiteit, 17 sept. 2009. Meppel: Uitgeverij Boom

Verstegen, M. (2014). Handboek Fondsenwerving. Peize: Tekst en Uitleg BV Waal, S. De. (2000). Nieuwe strategieën voor het publieke domein. Alphen a/d Rijn: Samsom

Waal, S.P.M. de. (2015). Burgerkracht met Burgermacht. Den Haag: Boom Lemma Uitgevers

Watzlawick, P., J. Helmick Beavin en Jackson, D. (1973). De pragmatische aspecten van de menselijke communicatie. Deventer:Van Loghum Slaterus

Westen, H. van der. (2013). Handboek sponsoring en fondsenwerving. Zutphen:Walburg Pers

WRR Werkprogramma 2015. Wetenschappelijk Raad voor het Regeringsbeleid. Den Haag

www.ernop.eu

wWW.EUFORISTUDY.eu 

